\title{
Intra-Industry Trading Factors and Patterns in Asean-5 Region
}

\author{
Muryani \& Anisa Dyan Pratiwi \\ Universitas Airlangga
}

\begin{abstract}
The large expansion of trade in the form of Intra-Industry Trade (IIT) in ASEAN is driving large volumes and variety of traded goods and is changing patterns of trade across members. This paper examines the factors affecting the level of IIT for ASEAN-5 countries (Indonesia, Malaysia, Philippines, Singapore, and Thailand) in the period of 2004-2014. IIT is measured with Grubel-Lloyd index covering ten different one-digit SITC categories. The result indicates a large Intra-Industry Trade among ASEAN countries and across most manufacturing sectors. IIT Index is employed as a dependent variable, and four variables are used as independent variables: 1) different GDP per capita, 2) foreign direct investment (FDI), 3) trade openness, and 4) distance. This research uses Pooled Least Square, Fixed Effect Model, dan Random Effect Model as tools of analysis. The main finding shows that different GDP per capita and trade openness have a positive effect on IIT. Meanwhile, FDI does not affect IIT, and distance has a negative effect on IIT across intra-ASEAN trade.
\end{abstract}

Keywords: International Trade, Intra-Industry Trade, Grubel-Lloyd, Panel Data Analysis

Ekspansi perdagangan yang besar dalam bentuk Perdagangan Intra Industri (IIT) di ASEAN mendorong volume besar dan berbagai barang yang diperdagangkan dan mengubah pola perdagangan antar anggota. Tulisan ini mengkaji faktorfaktor yang mempengaruhi tingkat IIT untuk negara-negara ASEAN-5 (Indonesia, Malaysia, Filipina, Singapura, dan Thailand) pada periode 2004-2014. IIT Index digunakan sebagaivariabel independen: 1) GDP per kapita yang berbeda, 2) investasi asing langsung (FDI), 3) keterbukaan perdagangan, dan 4) jarak. Penelitian ini menggunakan Pooled Least Square, Fixed Effect Model, dan Random Effect Model sebagai alat analisis. Temuan utama dalam penelitian ini menunjukkan bahwa perbedaan $P D B$ per kapita dan keterbukaan perdagangan memiliki efek positif pada IIT. Sementara FDI tidak mempengaruhi IIT, dan jarak memiliki efek negatif pada IIT di perdagangan intra-ASEAN.

Kata kunci: Perdagangan Internasional, Perdagangan Intra Industri, GrubelLloyd, Analisis Data Panel 
Since the 1960s, both developed and developing countries are somehow engaged in economic integration projects aiming to increase regional-global trade. For some East Asian countries, exports are a large contributor to Gross Domestic Product (GDP). In most recent decades, Japan, Korea, Taiwan, and Singapore have been implementing ambitious export-oriented strategies. In South Korea, the contribution of exports to GDP increased from $3 \%$ in 1960 to $46 \%$ in 2007. Similarly, Taiwan increases from $10 \%$ rise to $74 \%$ (Sawyer et al. 2010, 485). Besides, after the 1980s, Asia has rapidly moved towards a more integrated region, mainly dominated by intra-industry trade and strongly influenced by fragmented structures. Ando (2006) noted the increasing importance of vertical IIT in East Asia and the drop of one-way trade. Traditional comparative advantage theories more commonly explain one-way trade as in David Ricardo (differences in technology) and Heckscher-Ohlin (differences in factors of production). On the other hand, vertical-horizontal differentiation and production fragmentation theories explain Intra-Industry trade patterns (Ando 2006).

In a complex global system of trade, the two traditional comparative advantage theories are used to predict patterns of international trade. Currently, it is hard to find a fully specialized and self-sufficient country. Instead, nations tend to specialize partially and still trade within similar good's categories (Krugman \& Obstfeld 2003, 137). In other words, most economies no longer produce and trade homogeneous products, but differentiated ones. In most products, the degree of variation is wide, meaning that international trade can involve the large exchange of differentiated products, either drive by differences in quality, taste, incomes, or other factors. An international trade involving the exchange of products from the same industry sector is called Intra-Industry Trade (Salvatore 2014, 165). As noted in Kandogan (2003) IIT is constituted by horizontal IIT and vertical IIT. Horizontal IIT includes similar goods, both exported and imported, mainly driven by differentiation of same category goods. Vertical IIT includes exports and imports of products from the same industry, from the vertical disintegration of production due to varying factor intensities within an industry. However, the goods belong to different phases of production (Grubel and Lloyd 1975), often differentiated by quality or income (Linder 1961).

Krugman and Obstfeld (2003) explain that in the United States (US), manufactured goods dominate IIT trade. Inorganic-chemicals has an index of 0.99 while for footwear IIT index is only 0.00, meaning it only imports from the developing countries. IntraIndustry Trade is more frequently found in manufactured goods, mainly within SITC 5-8 (Sawyer et al., 2010; Athukorala \& Nasir 2012). Several studies show that distance is an important determinant factor in IIT trade (Balassa 1986 \& 1987; Sawyer et al. 2010; Shahbaz and Leitao 2010; Botrić 2013), while transport costs would reduce the volume of trade (Krugman 2003; Botrić 2013). Likewise, Krugman (2003) points out the need for information on the characteristics of product differentiation to reach higher IIT. Another positive determinant of IIT is Foreign Direct Investment (FDI), particularly if foreign affiliates are engaged in back-and-forth trade (Fukao et al. 2003). The complementarity of scarce factors of production of foreign companies with home recipient country (FDI recipient) provides opportunities for a wider differentiation of goods. Openness, employing as a proxy the share of trade from total GDP, is also expected to be positively related to IIT as it is associated with low trade barriers, resulting in larger trade volumes and commonly related to higher IIT levels.

While previous literature results show the existence of positive gains of IIT in ASEAN trade, patterns are dynamic, and factors are affecting IIT change over time. The large and dynamic economic improvements in ASEAN related to income growth, transportation, trade growth, and FDI inflows offer a room for new patterns in IIT determinants. This study estimates the IIT index from 2004 to 2014 covering the group categories from SITC o to SITC 9 for Indonesia, the Philippines, Malaysia, Singapore, 
and Thailand. This research uses the Grubel-Lloyd index to determine the magnitude of IIT, employing data panel. The variables employed are, 1) differences in per capita income, 2) geographic distance, 3) openness, and 4) Foreign Direct Investment.

\section{Intra-Industry Trade Model}

The current international trade includes Intra-Industry trade in different products, as opposed to Inter-Industry trade with completely different products (Salvatore 2014, 165). The main difference between Inter-Industry trade and Intra-Industry trade is that Inter-Industry trade is based on conventional comparative advantage theories (Ando 2006). For instance, if a country revealed advantages due to endowment proportions (Heckscher-Ohlin), then the country will export the factor-intensive good and will import the resource-scarce goods. In the Intra-Industry trade (IIT), even though trading countries have the same overall capital-labor ratios, their companies will still produce different products (Krugman \& Obstfeld 2003, 137) when taste, income or quality differ. While Inter-Industry trade mainly comprises one-way trade and its commonly explained by traditional comparative advantage theories, trade under intra-industry is more varied. IIT can either involve one-way trade, vertical IIT, or horizontal IIT (Ando 2006).

Another major difference between inter and intra-industry trade is that InterIndustrial trade takes place mainly within a perfectly competitive market structure with homogeneous goods. Intra-Industrial trade can take place even within the monopolistic competition market structure as it is mainly composed of differentiated goods, either horizontal or vertical differentiation (Ando 2006). The pattern of IntraIndustry trade is then less easy to predict, challenging to state trade patterns. While both countries might engage in trade, it is puzzling to determine who will produce which product and under which particular features (as they are likely differentiated goods).

Finally, the relative significance of Intra-Industry trade and Inter-Industrial trade might depend on how far the similarity of production factor abundance in the countries involved in the trade itself. If two countries have almost equal capital-labor ratios, then their Inter-Industrial trade transactions will be limited, whereas Intra-Industrial trade, principally based on economies of scale (production-distribution) and differentiation, will be dominant. On the other hand, if the capital-labor ratios of the two countries are so different, trade relations might be solely based on absolute advantage instead of Intra-Industry trade relations. Countries with high per capita income will demand highquality goods and often sophisticated capital goods. Conversely, countries with low per capita incomes will demand lower quality goods, and less sophisticated consumer and capital goods. Thus, the difference in per capita income is a potential barrier to trade.

Higher income countries that have a comparative advantage in the production of highquality goods will gain large export markets in other rich countries, where people's demand for these products is relatively high. On the contrary, rich countries might not have a potential market in developing countries where the demand for higher quality goods is lower. Thus, developing countries will also get their best markets in other developing countries that have similar demand structure. The hypothesis of Linder (1961) does not rule out the possibility of trade between developing countries with rich countries. However, if the overlap rate of the demand structure is small, the potential for manufacturing trade is also small. 


\section{Model Analysis and Research Method}

To analyze the determinants of Intra-Industry trade in the ASEAN-5 region, this study employs a gravity model based on panel data regression. The econometric equation is formulated as follows:

$$
\text { IIT }_{\text {it }}=\beta 0+\beta 1 \text { LNDCGDP }_{i t}+\beta 3 \text { FDI }_{i t}+\beta 4 \text { OPEN }_{i t}+\beta 5 \text { LNDIST }_{i t}+\varepsilon_{i t}
$$

\section{Note:}

$\begin{array}{ll}\text { IIT }_{\text {it }} & : \text { Intra-Industry trade index of ASEAN-5 countries in year t } \\ \begin{array}{ll}\text { DCGDP } \\ \text { their }\end{array} & : \text { Differences in per capita income between ASEAN-5 countries and } \\ & \text { three major trading partners in year t } \\ \text { FDI }_{\text {it }} & : \text { Foreign Direct Investment of each ASEAN-5 country in year t } \\ \text { OPEN }_{\text {it }} & : \text { Trade openness (trade openness) of each ASEAN-5 country in year t } \\ \text { DIST }_{\text {it }} & : \text { Geography distance between ASEAN-5 countries and their three major } \\ & \text { trading partners in year t } \\ \mathrm{E}_{\mathrm{it}} & : \text { Error term }\end{array}$

This research uses as an independent variable the IIT index, calculated using the Grubel-Lloyd formula in ten categories of SITC (all one-digit groups). Independent variables are; 1) differences per capita income, 2) Foreign Direct Investment, 3) trade openness, and 4) geographical distance. This study uses panel data regression, with cross-section data for ASEAN-5 and time series data in 2004-2014. The research data is sourced from a World Bank databased, United Nation commodity trade (UN Comtrade), as well as from a Geodata source.

The per capita income difference variable is derived from the first calculated absolute value of the GDP per-capita gap between the ASEAN-5 economies with three major trading partners; Japan, China, and the United States. Then natural logarithms are taken from the average of the three differences. FDI and trade openness variable were taken from the World Bank data and is presented in percent. The geographical distance is estimated from the natural logarithms measuring the average distance among trading partners in nautical miles. The distances are measured from the capital cities of Indonesia, Philippines, Malaysia, Singapore and Thailand with three major trading partners Japan, China, and the United States.

\section{Pooled Least Square, Fixed Effect Model, and Random Effect Model Analysis}

This study uses a panel data that is a combination of time series and cross-section data. Panel data can be estimated through Pooled Least Square (PLS), Fixed Effect Model (FEM) and Random Effect Model (REM). The appropriate method to be employed can be determined through three different tests, the F-restricted test, Hausman test, and the Lagrange Multiplier test. The F-restricted test is used to choose between Pooled 
Least Square (PLS) and Fixed Effect Model (FEM) methods. Hausman test is used to choose between Fixed Effect Model (FEM) and Random Effect Model (REM), while Lagrange Multiplier test is used to choose between Pooled Least Square (PLS) and Random Effect Model (REM).

This research uses Pooled Least Square, Fixed Effect Model, and Random Effect Model. FEM is not employed because there is unpredictable distance variable, because the deviation on the variable of Inter-country distance is very low, and the parameter cannot be estimated. The Lagrange Multiplier test is performed to choose between PLS and REM; the results show that PLS is better than REM. The results of PLS estimation are given below:

\section{Table 1. Regression Results Pooled Least Square}

\begin{tabular}{ll}
\hline Dependent Variable : Indeks IIT & \\
\hline Cons & -1.274282 \\
& $(0.264)$ \\
LNDCGDP & 0.256769 \\
& $(0.008)^{* *}$ \\
FDI & -0.0010602 \\
& $(0.557)$ \\
OPEN & 0.0009148 \\
& $(0.000)^{* * * *}$ \\
LNDIST & -0.0781975 \\
& $(0.084)^{* *}$ \\
\hline Number of obs & 55 \\
R-squared & 0.6629 \\
Adj R-Square & 0.6360 \\
Prob (F) & 0.0000 \\
Root MSE & 0.0376 \\
\hline
\end{tabular}

Note:

*** Significant level $1 \%$

** Significant

level $5 \%$

*Significant

level 10\%

Figures in ( ) state p-value

The result of the estimation model using Pooled Least Square are as follows:

IIT $_{\text {it }}=-1.274282+0.256769\left(\right.$ LNDCGDP $\left._{i t}\right)-0.0010602\left(\right.$ FDI $\left._{\mathrm{it}}\right)+$ $0.0009148\left(\right.$ OPEN $\left._{\mathrm{it}}\right)-0.0781975$

$\left(\right.$ LNDIST $\left._{i t}\right)+\varepsilon t \ldots \ldots \ldots \ldots \ldots \ldots \ldots \ldots \ldots \ldots \ldots \ldots \ldots \ldots \ldots \ldots$ 
Pooled Least Square model regression results in adjusted R2 of 0.6360 , meaning that 64 percent of independent variables can explain the dependent variables, while other variables outside independent variables explain the rest. The difference in income per capita (DCGDP) variable has a probability 0.008 means the probability is less than the $10 \%$ significant level ( $\alpha$ ); Ho is rejected. Accepting H1 means that the difference in income per capita (DCGDP) significantly affect Intra-Industry trade (IIT) in ASEAN-5 in the period 2004-2014. DCGDP has a coefficient value 0.256769 and positive indicating that every $1 \%$ increase in DCGDP will increase IIT by 0.257 percent. Among the four factors employed, differences in income levels reveal the strongest effect. The results of Botrić (2013) also indicates a strong effect of differences in incomes, particularly within vertical IIT (not within horizontal IIT), highly relevant in Asia (Ando 2006).

The Foreign Direct Investment (FDI) variable has a probability of 0.557. The probability value is greater than the significance level $(\alpha)$ ten percent means the FDI variable does not significantly affect the IIT variable. While some studies (Arnold \& Javorcik 2009) find FDI as a driver of fragmented structures (within IIT framework) in Indonesia, overall effects might not be the same for all ASEAN countries as it is also found in other studies in FDI and IIT (Brown et al. 2004). Considering the low capital intensity of Indonesia, Philippines, and Thailand, it may be expected that these countries would benefit from higher capital inflows as a process of catching up with more advanced nations. However, FDI is not significant perhaps denoting that exports from low capital income ASEAN countries is still mainly dependent on low capital and labor-intensive factors (even natural resource-based) as noted in Esquivias (2017).

Trade openness (OPEN) has a significant effect on Intra-Industry trade. In fact, the probability of a trade openness equal to 0.000 means that the probability value is less than the level of significance at ten percent. The trade openness variable has a coefficient value of 0.0009 and is positive. That is, every increase of one percent trade openness of ASEAN-5 countries IIT will increase by 0.00091 percent. Intra-Industry trade is highly related to fragmented structures were multiple-cross border transactions are needed indicating that openness is crucial for efficient service links. Having common trade regimes within ASEAN and partners (Japan, China, and United States) might offer important gains in IIT.

Esquivias Padilla et al., (2017) noted the large concentration of trade of ASEAN countries within the ASEAN Plus East Asian countries (including India), particularly within parts and components (an important element of IIT). Results of Okabe and Urata (2014) show positive effects of tariff eliminations on trade expansion, although smaller effects within the ASEAN 5 compare to the new members. The AFTA has been a successful driver of regional trade in ASEAN, while further gains might arise from further reducing non-tariff barriers. Even though openness offers positive impacts for IIT trade expansion, it is often found the low utilization rates of trade within ASEAN countries (Kohpaiboon 2010), offering further gains for ASEAN by implementing trade facilitation measures.

The distance variable (DIST) is expected to be negatively related to IIT index as the longer the distance, the higher expected cost. The distance coefficient value with three major ASEAN- 5 trading partners is -0.078 , means that the closer the countries the larger the IIT among them. DIST has a probability value of 0.084 . The value indicates a significance level $(\alpha)$ ten percent means that significant distance variables affect IIT. Singapore and Malaysia reported the largest trade flows under IIT, either due to distance as well as the other variables employed. 


\section{IIT Pattern in ASEAN-5}

Graph 1, shows the development of Intra-Industry trade in the ASEAN-5 region. The graph shows the ASEAN-5 countries have a high IIT, with an average of 0.69 in Indonesia, Malaysia 0.84, Philippines 0.76, Singapore 0.84, and Thailand 0.78. Although Indonesia, Malaysia, Philippines, and Thailand are still classified as middle-income country, they also record high IIT. A possible reason is the process of implementation of the ASEAN Free Trade Area (AFTA) in which the ASEAN-5 countries are the most active members. The period of analysis (2004-2014) covers special milestones in the implementation of the AFTA, with particularly large improvements in tariff reductions and barrier removals. The ASEAN displays specialization and advantage within a wide range of manufacturing goods allowing for trade in differentiated goods. Particularly, the differences in incomes when comparing Singapore-Malaysia with IndonesiaPhilippines-Thailand might also support the expansion of vertical IIT under different income levels.

\section{Graph 1.}

\section{Average of SITC o-9 in ASEAN 5 Region}

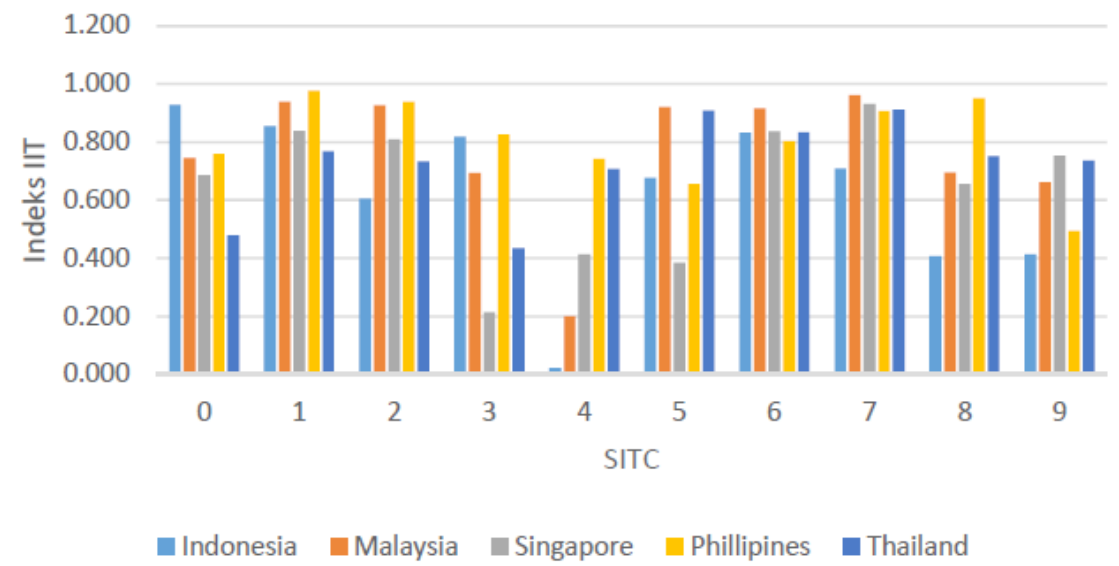

Sources: Processed from UN Comtrade

The ASEAN region is also highly integrated into international trade networks (Sawyer et al. 2010, 489), and is heavily engaged in trade of Intermediate parts and components (Athukorala and Yamashita 2006; Ando 2006; Esquivias Padilla et al. 2017). For example, disk drive production in Thailand involves a production network covering nine Asian countries, plus Mexico and the United States.

Singapore a leader in high technologies, a large trader (400\% trade to GDP ratio), and categorized as developed country reports particularly high IIT, meaning a high dependency on IIT trade structures, and the most open ASEAN country. Singapore and Malaysia account for a large portion of regional trade within ASEAN. Developed countries typically have higher IIT levels than developing countries as higher per capita GDP levels are associated with larger and more diverse product baskets (larger and more diversified demand). However, developing ASEAN countries are catching up at a rapid speed in Asian international networks within IIT, particularly within machinery, electronics, and transport equipment sector. While Singapore is the most open country in ASEAN with 406\% (trade to GDP ratio), Indonesia is the less open one (48\%). 
From Graph 1, it is seen that IIT is high despite the primary goods category SITC 0-4 where most ASEAN-5 are active exporters (Esquivias 2017). Although visible, the corresponding IIT levels of SITC o, SITC, 3, and SITC 4 are below the overall ASEAN average IIT (0.71). Among primary goods sectors, SITC 1 (beverage and tobacco products) and SITC 2 (crude materials) (see table 2) report higher than average IIT index. That is, IIT on primary products tends to be lower than those of manufactured products. Surprisingly, the highest level of IIT in the ASEAN- 5 region are within the category of SITC 0-4 as these countries import raw materials, reprocess them, and reexports to the World (Sawyer et al. 2010, 490). For example, in Malaysia and Singapore, the imports of crude oil are large, as they engaged in import, re-process and re-export into higher value-added oil derivative goods.

The SITC Category 5 (chemicals), 6 (manufactured goods), 7 (machinery and transport) has an IIT index higher than the overall average SITC, indicating the prevalence of IIT trade within manufactured goods. Except for SITC 8 (miscellaneous manufactures) that has a lower IIT average as ASEAN-5 countries tend to export more in that category to non-ASEAN markets. SITC 9 includes goods and transactions that are not classified elsewhere making it difficult to interpret the results (Sawyer et al. 2010, 490). Indonesia plays an active role within SITC o, 1, 3, and 6, but a lower one in 5, 7, 8, and 9 where Singapore, Malaysia, and Thailand have larger IIT indexes. Malaysia and Thailand have the largest IIT within SITC 5-7 (chemical, manufactured goods, and machinerytransport goods), special sectors within Asia production networks.

Table 2. Average of SITC O-9 ASEAN-5

\begin{tabular}{|l|c|c|c|c|c|c|c|c|c|c|}
\hline & 0 & 1 & 2 & 3 & 4 & 5 & 6 & 7 & 8 & 9 \\
\hline Average & 0,70 & 0,87 & 0,80 & 0,59 & 0,41 & 0,71 & 0,84 & 0,88 & 0,69 & 0,61 \\
\hline
\end{tabular}

\section{IIT Determinants in ASEAN-5}

This study aims to determine the determinants of IIT in the ASEAN- 5 region. All goods traded by the ASEAN-5 countries under SITC groups 0-9 are included. According to Helpman and Krugman (1985), similarities in factors of production between trading nations determines in some degree the existence of horizontal IIT across partners. On the other hand, differences in income levels are more often associated with high IIT under vertically differentiated goods (Flam \& Helpman 1987). Similarities of factors are capture by employing a difference in GDP per capita (DCGDP). The difference in per capita income captures the variation in demand for differentiated products in the trading partner. Horizontal IIT is expected to be more intensive in countries with per capita income levels that are rather similar. If per capita income is different from trading partner countries, horizontal IIT might be lower, but vertical IIT might increase. Therefore, per capita income has a negative effect for horizontal IIT and positive for vertical IIT.

The results indicate that differences in GDP per capita among ASEAN-5 countries have a positive and significant effect on IIT, meaning that is more strongly supporting vertical IIT rather than horizontal IIT. Incomes across ASEAN countries differ enough to create a higher need for differentiated goods and promoting the presence of a wider variety of products. Similarly, some ASEAN-5 countries are experiencing intense trade in vertically differentiated products with high-income countries like Japan and the United States (Sawyer et al. 2010, 490), and more recently with China (Esquivias Padilla et al. 2017). 
Foreign Direct Investment (FDI) is often presented as a driver of a country's export and simultaneously as an accelerator to transition from low to high value-added products. Developing countries typically lack sophisticated technology, while multinational companies could bring advanced technology and product knowledge through FDI to developing countries. FDI then could help increase the production capacity and varieties of host countries. FDI is expected to increase IIT, especially if foreign affiliates are formed to take advantage of production factors from the host countries, and their subsequent production is re-exported to the origin country or re-exported to the World.

Several studies have shown different results for FDI variables. Balassa (1987) study reveals that FDI is negatively associated with IIT. As a measure of the upsurge of foreign markets, exports provide a place for FDI by oligopolistic companies that exploit the inherent possibilities in their product differential characteristics, meaning that FDI is negatively related to IIT. In contrast to Balassa, Xing (2007) shows FDI as being positively related to exports. Sawyer et al., (2010), Shahbaz and Leitao (2011) show that FDI is not significant against IIT.

This study finds that FDI does not has a significant effect on the IIT index. A substantial share of FDI is intended to serve the host country's domestic market because it focuses more on trade costs such as transportation and tariffs so that the affiliated company does not export back to the origin country (Sawyer et al. 2010, 492). Xing (2007) explains the long distance between countries causes the low levels of Intra-firm trade between foreign affiliates in the ASEAN-5 region with its parent company. The High cost of transportation is associated with long distance and can prevent the parent company from widely trade with its subsidiaries.

Trade openness is expected to have a positive effect on IIT. Low trade barriers can increase the trading volume of goods and services between countries thus creating a broad market. The results of this study indicate that the trade openness significantly and positively affects IIT. Devadason, Subramaniam, \& Baharumshah (2015) pointed out the need for more strategic partnerships of ASEAN, meaning greater efforts are needed to achieve larger gains through liberalization and integration.

In accordance with existing theory, trade could not be separated from transportation costs. Krugman (1980) states that transportation costs will reduce trade volume. In the case of Intra-Industry, differentiated goods, also demand large information and coordination, possibly adding to the cost of transportation when coordination is hard. Bigger transport cost (associated with distance) has a negative influence on IntraIndustry trade. Several studies use distance among their set of variables to determine impacts towards IIT index, i.e., Balassa (1986), Sawyer (2010), Yoshida (2013), Shahbaz \& Leitao (2010), Kandogan (2003), Stanley (1999) and Okabe (2014). Most of these studies find that distance has a negative effect on IIT, in line with the results of this study. Esquivias Padilla et al., (2017) noted that the largest expansion of ASEAN countries within vertical structures are within Asian markets, while North America and Europe are losing share in production networks with ASEAN countries.

\section{Conclusions}

This paper examines the factors determining the level of IIT for ASEAN- 5 countries (Indonesia, Malaysia, Philippines, Singapore, and Thailand) in the period of 20042014, covering all ten one digit SITC categories. The results of this study indicate that all ASEAN-5 countries recorded high IIT index. Malaysia and Singapore are the countries with the highest IIT index with an average of 0.84 , while Indonesia is the country with the lowest IIT index with an average of 0.69. The IIT index in the ten SITC categories 
in the ASEAN- 5 countries has a high IIT index in almost all SITC categories supporting the point that intra-industry trade is relevant for ASEAN export expansion. ASEAN trade within IIT reveals important patterns as even among basic goods; some sectors also account for large IIT index (beverage \& tobacco, and crude materials).

The variables employed in this study offer mix results. Difference income per capita (DCGDP) has a positive and significant impact on IIT, associated with vertical structures (vertically differentiated goods). Foreign Direct Investment (FDI) does not significantly influence IIT, although ASEAN received large sums. Trade openness reports significant and positive effect on IIT signaling the success of ASEAN integration project and the importance of trade policy for further trade deepening. Geographical distance affects significantly and negatively IIT Index with implications in transportation cost. The differences in per capita income, Foreign Direct Investment, trade openness and geographical distance jointly significantly affect the IIT (dependent variable).

Intra-Industry trade in ASEAN region appears more strongly supported in vertically differentiated goods within manufacturing groups (SITC 4-9), while more horizontally differentiated within agricultural resource-based sectors (SITC o -4).

For future research, a more detailed decomposition of IIT into its vertical and horizontal components might offer valuable results as different theoretical approaches might give insights on factors affecting different sectors. Considering the diversity of the ASEAN region, including additional variables, as country size, liberalization agreements, as well as including the missing members (particularly Viet Nam) and ASEAN Strategic members (China, India, S. Korea, Australia, New Zeeland, Japan) might offer high impact results.

\section{References}

\section{Book}

Appleyard, D., Field, A. and Cobb, S. 2005. International Economics, 5th edition, McGraw-Hill.

Grubel, H.G., \& Lloyd, P. J. 1975. Intra Industry Trade: The Theory and Measurement in

Differentiated Products. London: MacMillan.

Helpman, E, \& Krugman, P. 1985. Market Structure and Foreign Trade. Cambridge: MIT Press.

Krugman, P. R \& Maurice Obstfeld. 2003. International Economics: Theory and policy, 6/E. Pearson Education India

Salvatore, D. 2014. Ekonomi Internasional. Edisi Kesembilan. Salemba Empat: Jakarta.

\section{Journal and Online Journal}

Ando, M. 2006. Fragmentation and vertical intra-industry trade in East Asia. The North American Journal of Economics and Finance, 17 (3): 257-281. https:// doi.org/10.1016/j.najef.2006.06.005 
Arnold, J., \& Javorcik, B. S. 2009. Gifted Kids or Pushy Parents? Foreign Direct Investment and Plant Productivity in Indonesia. Journal of International Economics, 79 (1), 42-53.

Athukorala, P.-C., \& Nasir, S. 2012. Global production sharing and south-south trade. Indian Growth and Development Review, 5 (2), 173-202.

Balassa, B. 1986. Intra-industry specialization a cross-country analysis. European Economic Review, 30: 27-34.

Balassa, B. and L. Bauwens. 1987. Intra-Industry Specialization in a Multi-Country And Multi-Industry Framework. The Economic Journal, 97 (388): 923-939.

Botrić, V. 2013. Determinants of intra-industry trade between Western Balkans and EU-15: Evidence from bilateral data. International Journal of Economic Sciences and Applied Research, 6 (2): 7-23.

Caves, R. E. 1981. Intra-industry trade and market structure in the industrial countries. Oxford Economic Papers, 203-223.

Clark, D. P., \& Stanley, D. L. 1999. Determinants of intra-industry trade between developing countries and the United States. Journal of Economic Development, 24 (2): 79-95.

Devadason, E. S., Subramaniam, T., \& Baharumshah, A. Z. (2015). Rebalancing Exports through Expansions in Intra-ASEAN Trade? Insights from Gravity Panel Estimates. Journal of Economic Cooperation and Development, 36 (4): 77-106.

Esquivias Padilla, M. A, Sari, D. W, \& Handoyo, R. D. 2017. Formation of production networks in ASEAN: Measuring the real value-added and identifying the role of ASEAN countries in the world supply chains. Business and Economic Horizons, 13 (2): 237-255. http://dx.doi.org/10.15208/beh.2017.18

Esquivias, M. A. 2017. The Change of Comparative Advantage of Agricultural Activities in East Java Within the Context of Asean Economic Integration. AGRIS On-Line Papers in Economics and Informatics, 9 (1): 33-47. https://doi.org/10.716o/ aol.2017.090103.

Fukao, K., Ishido, H., \& Ito, K. 2003. Vertical intra-industry trade and foreign direct investment in East Asia. Journal of the Japanese and International Economies, 17 (4): 468-506. https://doi.org/10.1016/j.jjie.2003.09.004

Helpman, E. 1981. International trade in the presence of product differentiation, economies of scale and monopolistic competition: A Chamberlin-HeckscherOhlin approach. Journal of international economics, 11 (3): 305-340.

Kandoga, Y. 2003. Intra-industry trade of transition countries: trends and determinants. Emerging Markets Review, 4 (3): 273-286

Krugman, P. 1980. Scale economies, product differentiation, and the pattern of trade. The American Economic Review, 950-959.

Linder, S. B. 1961. An essay on trade and transformation. Stockholm: Almqvist \& Wiksell, 82-109.

Okabe, M., \& Urata, S. 2014. The impact of AFTA on intra-AFTA trade. Journal of Asian Economics, 35: 12-31. 
Sawyer, W. C., Sprinkle, R. L., \& Tochkov, K. 2010. Patterns and determinants of intraindustry trade in Asia. Journal of Asian Economics, 21 (5): 485-493.

Xing, Y. 2007. Foreign direct investment and China's bilateral intra-industry trade with Japan and the US. Journal of Asian Economics, 18 (4): 685-700.

Yoshida, Y. 2013. Intra-industry trade, fragmentation and export margins: An empirical examination of sub-regional international trade. The North American Journal of Economics and Finance, 24: 125-138..

\section{Others}

Shahbaz, Muhammad and Nuno Carlos Leitao. 2010. Intra-Industry Trade: The Pakistan Experience. International Journal of Applied Economics, 7 (1), March 2010. Annual Report 2011 (Online)

Kohpaiboon, A. 2010. 'Exporters' Response to FTA Tariff Preferences: Evidence from Thailand', RIETI Discussion Paper Series, No. 10-E-039, Tokyo: RIETI. 